\title{
Fusarium mycotoxin content and Fusarium species presence in Czech organic and
}

\section{conventional wheat}

\author{
I. Polišenská ${ }^{*}$, O. Jirsa ${ }^{1}$, J. Salava ${ }^{2}$, I. Sedláčková ${ }^{1}$ and J. Frydrych ${ }^{3}$ \\ ${ }^{1}$ Agrotest Fyto, Ltd., Havličkova 2787, 76701 Kroměřiž, Czech Republic; ${ }^{2}$ Crop Research Institute, Drnovská 507/73, 16106 \\ Praha-Ruzyně, Czech Republic; ${ }^{3}$ OSEVA Development and Research, Ltd., Hamerská 698, 756 54 Zubří, Czech Republic; \\ polisenska@vukrom.cz
}

Received: 5 June 2020 / Accepted: 25 September 2020

(C) 2021 Wageningen Academic Publishers

OPEN ACCESS CC) (1) (2) RESEARCH ARTICLE

\begin{abstract}
Deoxynivalenol and zearalenone content and the presence of Fusarium species in organically and conventionally grown wheat harvested in the Czech Republic during 2015-2017 were studied. Mycotoxin contamination was compared using two approaches. The first was based on samples taken from randomly selected farms in individual regions of the Czech Republic, both organic (154 samples) and conventional (330 samples). In the second approach, a sample set of conventional wheat compatible with organic one was formed, with samples paired according to the preceding crop and region of harvest. Using the first approach, mycotoxins were shown to be higher in conventional wheat; however, there was no difference in mycotoxin contamination between organic and conventional wheat using the second approach. Eight wheat samples with mycotoxin content above the EU limits were found, seven for deoxynivalenol (2.1\%) and one for zearalenone (0.3\%), all of them originated from conventional farming system. Six of them had maize as the preceding crop. The presence of five Fusarium species (Fusarium avenaceum, Fusarium culmorum, Fusarium graminearum, Fusarium poae and Fusarium sporotrichioides) was compared for the compatible wheat sample sets (second approach). The predominant species were found to be F. poae and F. graminearum in both the organic and conventional wheat. Harvest year significantly influenced both the occurrence of the main Fusarium species and the level of mycotoxin contamination. The study confirmed that (a) organic farming system was able to keep mycotoxin contamination of wheat at a low level, (b) in studies on the significance of organic/conventional agricultural practice on mycotoxin levels in cereals, it is important to pay attention to common production and environmental variables.
\end{abstract}

Keywords: deoxynivalenol, zearalenone, organic system, conventional system, comparison

\section{Introduction}

Fusarium head blight (FHB), caused by a complex of several Fusarium species, is a destructive fungal disease of wheat and other small-grain cereals. The composition of the Fusarium pathogen complex occurring on cereal heads is variable and influenced by many factors, of which geographical factors, including climate, are the most important (Doohan et al., 2003; Schaafsma and Hooker, 2007; Xu et al., 2008). The preceding crop, soil cultivation method, variety, fungicide use and many other factors can also have a significant impact (Bernhoft et al., 2012; Edwards, 2004; Lori et al., 2009). In general, FHB in small-grain cereals is mainly caused by Fusarium avenaceum, Fusarium culmorum, Fusarium graminearum, Fusarium poae, Microdochium nivale and Microdochium majus (Becher et al., 2013; Mesterházy, 2003). Most of Fusarium species can contaminate the cereal grain with mycotoxins. Broad variability in mycotoxin spectra and concentrations in the harvested grain exists as a consequence of the variability in the composition of the Fusarium pathogen complex. The content of some of the toxic Fusarium metabolites in food and raw materials is limited. For unprocessed common wheat (Triticum aestivum), a limit of $1,250 \mu \mathrm{g} / \mathrm{kg}$ for deoxynivalenol (DON) and $100 \mu \mathrm{g} / \mathrm{kg}$ for zearalenone (ZEN) is set by the Commission Regulation (EC) No. 1881/2006 (EC, 2006). The main producers of DON 
and ZEN are F. graminearum and F. culmorum (Desjardins, 2006; Kokkonen et al., 2010).

Organic farming is primarily perceived by the public as farming in which synthetic pesticides and mineral fertilisers are not used, in contrast to conventional one. In a broader sense, organic farming is defined as the production system that sustains the health of soils, ecosystems and people. It relies on ecological processes, biodiversity and cycles adapted to local conditions, rather than on the use of inputs with adverse effects. Organic disease management strategies should be largely preventive and depend on the whole system approach, with maintenance of the soil health as a central component of any strategy (Davies et al., 2002). To the most important pillars of organic plant protection strategy belong the choice of appropriate species and varieties resistant to pests and diseases and appropriate crop rotations (EC, 2007). In the Czech conventional wheat production practice, the importance of crop rotation in control of FHB has often been neglected and the increased intensity of FHB disease has been attributed just to the widespread adoption of minimum tillage and crop rotations with host crops (Váňová et al., 2008). Bread wheat is the most frequently grown cereal crop in both organic and conventional farming in the Czech Republic (CR). In 2015, wheat was grown on $10 \%$ of the total organic arable land and the yield of organic wheat was at the level of $50 \%$ of conventional wheat (Hrabalová, 2016).

The coexistence of organic and conventional farming is accompanied by discussions on the comparison of quality and health safety of their agricultural products. The absence of fungicides in organic farming gives rise to a question regarding the contamination of organic production by mycotoxins. A comparison of mycotoxin contamination in cereals from organic and conventional farming can be made using different approaches, such as exact field trials, farm survey or basket survey. Each approach has its justification, and its information ability is different. In field trials, the variability of environmental conditions, such as soil properties and local weather, is well eliminated, but it cannot convey the real situation in practice. On another note, a basket survey is conducted at the level closest to the consumers and can be most useful for exposure risk assessment; however, due to anonymous foodstuff origin, it cannot examine individual factors. Farm survey is based on samples collected directly from the farmers and shows the real situation at the entry into food chain, before processing. An additional value of this approach is that it enables feedback towards farmers.

Several studies have compared the occurrence of Fusarium mycotoxin contamination between conventional and organic cereal production, especially since the mid-1990s. Based on data originating from farm surveys, Gimenez et al. (2012), Hoogenboom et al. (2008), Malmauret et al.
(2002), Marx et al. (1995) and Edwards (2009) found no significant difference between DON contamination in conventionally and organically grown wheat. Kirinčič et al. (2015) reported higher DON content in organic wheat, similarly to Perkowski et al. (2007). Contrarily, Harcz et al. (2007), Meister (2009) and Vogelsgang et al. (2019) reported less DON contamination in organic wheat. In all of these studies, the sets of conventionally and organically grown wheat differed in sample number, preceding crop composition, variety and place of cultivation.

Lester and Saftner (2011) concluded that the main reason why the results of the studies comparing the properties of organically and conventionally grown production varied is because the sample sets from organic and conventional farming were not comparable. As they suggested, only pairwise complementary sample sets, that is, sample sets that only differ in the way of cultivation, have a real explanatory power. Some of these requirements were taken in consideration in a farm survey, which compared mycotoxin contamination and presence of Fusarium species in organically and conventionally grown cereals. Examining a total of 602 barley, oats and wheat samples (301 pairs of organically and conventionally grown wheat), significantly lower incidence of Fusarium pathogens and lower DON and HT-2 toxin concentrations were observed in organic cereals (Bernhoft et al., 2010).

In the CR, information from field trials is available. Váňová et al. (2008) found lower DON content in organic compared with conventional wheat, but only if it was grown under low and medium cropping intensity (one to two fungicide applications per vegetation period). Compared with wheat grown under high cropping intensity (four fungicide applications per vegetation period), there was no significant difference in the DON content between organic and conventional wheat. Petr and Reisnerová (2009) found mostly very low mycotoxin contents below or near the limit of detection in cereals obtained from both farming systems, and they concluded that in organic cereals, mycotoxin content was not higher than that in conventional cereals. However, information based on the analysis of the cereals grown in common agricultural practice have still been lacking.

The main aim of this study was to compare the contamination between organically and conventionally grown wheat in terms of the legislatively limited mycotoxins, DON and ZEN, sampled at the farm level using two approaches. Apart from the mycotoxin content, the presence of $F$. avenaceum, F. culmorum, F. graminearum, F. poae and Fusarium sporotrichioides was examined. 


\section{Materials and methods}

\section{Weather information}

The weather database of the Czech Hydrometeorological Institute was utilised for gathering climate data (Czech Hydrometeorological Institute, 2019). The average values for the CR of the mean air temperature and the sum of precipitation for each month from May to July in the harvest years 2015-2017 were collected (Figure 1). The highest total rainfall was recorded in 2016, both through the whole 3 -month period of May-July and in individual months. The wet weather character in 2016 was accompanied by middle temperatures. The lowest total rainfall was recorded in 2015, with profound lack of rainfall mainly in July, which was accompanied by the highest July temperatures of all years under study. On the contrary, the lowest temperatures were in May and June 2015.

\section{Wheat sampling}

The study was conducted on wheat harvested in CR in 3 harvest years (2015-2017). The organic wheat samples were collected from farms certified in accordance with the current legislation for organic farming. In individual years, 48 (2015), 53 (2016) and 53 (2017) organic wheat samples were collected, creating a set of 154 organically grown wheat samples (ORG). Two sets of conventional wheat samples were formed. CONV-I contained 330 wheat samples, 110 of which were sampled each harvest year, with sample numbers approximately corresponding to

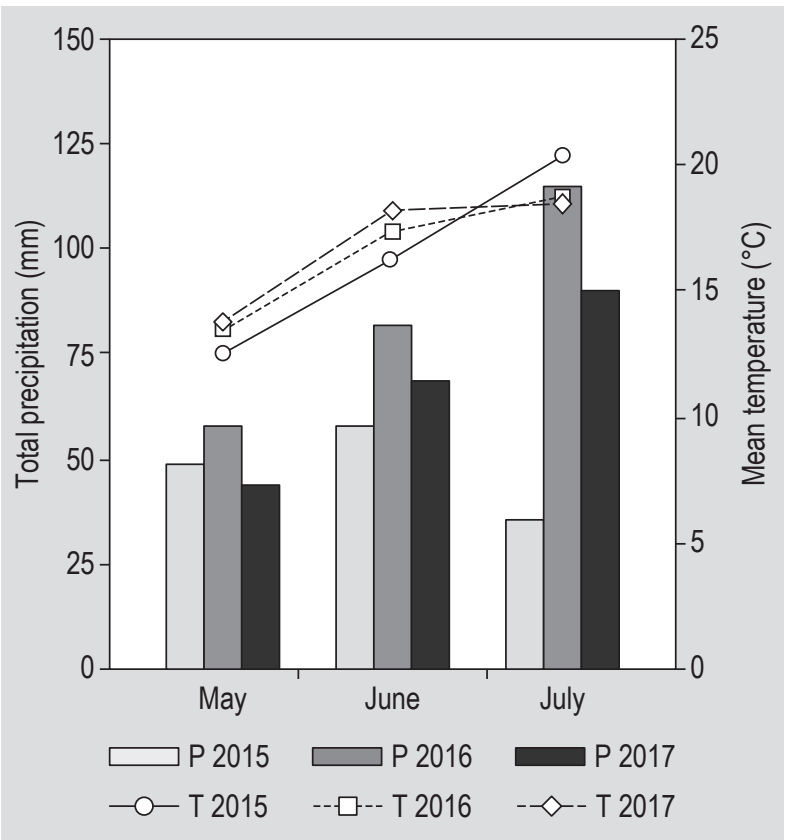

Figure 1. Monthly mean temperature and sum of precipitation in May-July period (2015-2017), the average values for the Czech Republic. the conventional wheat-growing area in individual regions (Supplementary Table S1).

CONV-II was formed as a paired sample set to the ORG set, with respect to the region of harvest (district) and preceding crop. Therefore, CONV-II contained 154 wheat samples just as many as ORG. CONV-II was partially a subset of CONV-I, with $27 \%$ of the CONV-II samples originated from CONV-I. The other samples had to be sought in a targeted way from farmers due to the specific requirements for preceding crop and growing site. For the purpose of sample matching, the preceding crops were grouped into four groups: (A) small-grain cereal crops (wheat, barley, spelt, rye, triticale, oats and sorghum), (B) maize (both for grain and silage), (C) non-host preceding crops (oilseed crops: oilseed rape, mustard, sunflower and poppy; forage crops: alfalfa, clover, grass, lupine, field pea, ryegrass and their mixtures) and (D) other preceding crops (potatoes, beet, buckwheat, legumes, vegetables and herbs). The composition of preceding crops in each sample set is presented in Figure 2.

The varietal composition was widely diverse. There were 36 different varieties in the ORG set, with Bohemia and Scaro occurring most frequently at 14\% (Supplementary Table S2). In the CONV-I set, 84 different varieties were involved, most frequently Tobak (9\%), followed by Genius (8\%) and Bohemia (5\%). In the CONV-II set, 55 different varieties were involved, most frequently Genius (8\%),

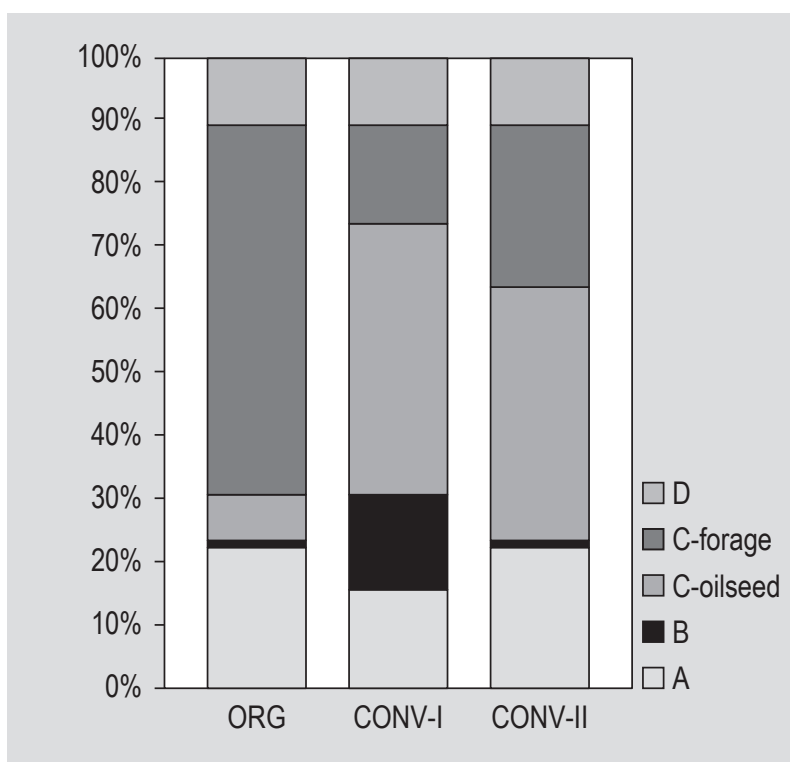

Figure 2. Preceding crops in individual wheat sample sets. ORG = set of 154 organic wheat samples; CONV-I = set of 330 samples representing Czech conventional wheat harvest, 110 each harvest year; CONV-II = set of 154 wheat samples compatible to ORG, samples were paired based on location and preceding crop; $A$ = small grain cereal crops; $B$ = maize; C = non-host crops; $D=$ other crops. 
followed by Bohemia (7\%) and Pannonia (6\%). Wheat sampling at the farm level was performed using a network of cooperating farms that has been working for many years, for official sampling to monitor the harvest quality of cereals in the CR and also through the mediation of agricultural consultants and the organic growers association, as well as the direct relationships between the laboratory personnel and the farmers. The samples were collected at the time of harvest by growers or consultants. Approximately $200 \mathrm{~g}$ of subsamples was taken from 10 randomly chosen sampling points, and these were mixed to obtain a $2 \mathrm{~kg}$ sample. The samples were placed inside paper bags and delivered to the laboratory on the same day or, at the latest, on the day following the collection. Each sample was accompanied by related agronomic data, including harvest location (plot, place and district), preceding crop and variety.

\section{Sample preparation}

Grain samples were carefully mixed. A 200 g laboratory sample was obtained using a laboratory sample divider. The grain was ground into whole meal flour using a sample mill Pulverisette 19 (Fritsch, Idar-Oberstein, Germany) with a $1 \mathrm{~mm}$ screen. The samples were stored at $-20{ }^{\circ} \mathrm{C}$ until mycotoxin analyses and detection and determination of Fusarium spp.

\section{Mycotoxin analyses}

DON and ZEN in whole meal flour were analysed by ELISA method using RIDASCREEN kits (R-Biopharm AG, Darmstadt, Germany) according to the manufacturer's instructions. The limit of quantification (LOQ) for DON was $20 \mu \mathrm{g} / \mathrm{kg}$, for ZEN $2 \mu \mathrm{g} / \mathrm{kg}$. The methods have been accredited in the laboratory according to standard EN ISO/ IEC 17025, and validation was performed to the extent needed to comply with the standard's requirements. DON and ZEN contents were analysed for all collected wheat samples.

\section{Fusarium spp. detection and determination}

The total DNA was extracted from milled wheat grain samples using the DNeasy Plant Mini Kit (QIAGEN, Hilden, Germany) according to the manufacturer's instructions. Primer sequences, polymerase chain reaction mixture and conditions for detecting six Fusarium spp. in this study were applied as described by Schilling et al. (1996) for $F$. graminearum and F. culmorum, Wilson et al. (2004) for $F$. sporotrichioides, Turner et al. (1998) for F. avenaceum and Parry and Nicholson (1996) for F. poae. The detection and determination of Fusarium species were performed for the 308 samples, i.e. for 154 pairs of organic (ORG) and conventional (CONV-II) samples.

\section{Data analyses}

Mycotoxin contamination was evaluated using average, median, minimum and maximum values, positive sample percentage (samples with mycotoxin content above their respective LOQ) and 90\% percentile. For calculations with mycotoxin values, the results reported as below LOQ were replaced by half of their respective LOQs (middle-bound estimate). Log-transformed mycotoxin values were used for calculations. The significance of the differences in mycotoxin content was evaluated by $t$-test at a level of $P=0.05$ for each of the harvest years, as well as for the total data set (Tukey's HSD test). The pathogen incidence rates were compared using chi-square test. All calculations were performed using the software package Statistica version 12 (StatSoft Inc., Tulsa, OK, USA).

\section{Results}

\section{Fusarium infestation}

No significant difference was observed in the total Fusarium presence between ORG and CONV-II (Figure 3). For individual Fusarium species, the difference was observed only in F. avenaceum, being found more often in conventionally grown wheat $(P=0.018) . F$. poae was the most common species, which was found in the mean of the 3 harvest years in $44 \%$ of ORG and $47 \%$ of CONV-II wheat samples. The second most frequent species was $F$. graminearum, which was found in 38\% of ORG and $45 \%$ of CONV-II wheat samples. The third most frequent was F. sporotrichioides (13\% ORG, 11\% CONV-II), followed by F. avenaceum (1\% ORG, 6\% CONV-II) and F. culmorum (2\% ORG, 3\% CONV-II).

The year significantly affected the occurrence of Fusarium pathogens for both organic and conventional wheat (Table 1). Fusarium pathogens were significantly more common in 2016 and 2017 than in 2015. F. poae most frequently occurred in 2017, being detected in $75 \%$ of ORG and $85 \%$ of CONV-II wheat samples, whereas it was not detected at all in 2015. F. graminearum was most commonly found in 2016 (79\% of ORG, 77\% CONV-II). F. sporotrichioides was detected in 2017 in $40 \%$ of ORG and 32\% of CONVII wheat, whereas it was not found in any sample in 2015 and 2016.

\section{Mycotoxin contamination}

In the ORG set, the proportion of DON-positive samples was $12 \%$ on average of the 3 harvest years, in individual years, the proportions were 2, 26 and 6\%, respectively. The mean DON content was below LOQ, and the maximum observed value reached $314 \mu \mathrm{g} / \mathrm{kg}$ (Table 2). In CONV-I, the proportion of DON-positive samples was $21 \%(10,37$ and $15 \%$ in individual years), with the mean value of 80 
Table 1. Frequency of Fusarium spp. incidence in individual harvest years in organic and conventional wheat. ${ }^{1}$

\begin{tabular}{|c|c|c|c|c|}
\hline Fusarium species & Year & ORG & CONV-II & $P$-value ${ }^{2}$ \\
\hline \multirow[t]{3}{*}{ F. culmorum } & 2015 & $0 \%$ & $8 \%$ & 0.041 \\
\hline & 2016 & $0 \%$ & $2 \%$ & 0.32 \\
\hline & 2017 & $6 \%$ & $0 \%$ & 0.079 \\
\hline$P$-value ${ }^{3}$ & & 0.054 & 0.049 & \\
\hline \multirow[t]{4}{*}{ F. graminearum } & 2015 & $27 \%$ & $38 \%$ & 0.28 \\
\hline & 2016 & $79 \%$ & $77 \%$ & 0.81 \\
\hline & 2017 & $8 \%$ & $21 \%$ & 0.051 \\
\hline & & 0.000 & 0.000 & \\
\hline \multirow[t]{3}{*}{ F. poae } & 2015 & $0 \%$ & $0 \%$ & - \\
\hline & 2016 & $53 \%$ & $53 \%$ & - \\
\hline & 2017 & $75 \%$ & $85 \%$ & 0.22 \\
\hline$P$-value ${ }^{3}$ & & 0.000 & 0.000 & \\
\hline \multirow[t]{3}{*}{ F. avenaceum } & 2015 & $0 \%$ & $0 \%$ & - \\
\hline & 2016 & $0 \%$ & $13 \%$ & 0.006 \\
\hline & 2017 & $4 \%$ & $6 \%$ & 0.65 \\
\hline$P$-value ${ }^{3}$ & & 0.15 & 0.026 & \\
\hline \multirow[t]{3}{*}{ F. sporotrichioides } & 2015 & $0 \%$ & $0 \%$ & - \\
\hline & 2016 & $0 \%$ & $0 \%$ & - \\
\hline & 2017 & $40 \%$ & $32 \%$ & 0.55 \\
\hline$P$-value ${ }^{3}$ & & 0.000 & 0.000 & \\
\hline \multirow[t]{3}{*}{ Total Fusarium } & 2015 & $27 \%$ & $42 \%$ & 0.13 \\
\hline & 2016 & $92 \%$ & $87 \%$ & 0.34 \\
\hline & 2017 & $91 \%$ & $87 \%$ & 0.54 \\
\hline$P$-value ${ }^{3}$ & & 0.000 & 0.000 & \\
\hline $\begin{array}{l}{ }^{1} \mathrm{ORG}=\text { set of } 154 \\
\text { wheat samples com } \\
\text { location and preced } \\
2 P \text {-value is related } \\
\text { organic and conven } \\
{ }^{3} P \text {-value is related } \\
\text { individual harvest y }\end{array}$ & $\begin{array}{l}\text { patible to } \\
\text { ing crop. } \\
\text { to differe } \\
\text { tional wh } \\
\text { to differe } \\
\text { ars. }\end{array}$ & $\begin{array}{l}\text {, samp } \\
\text { in the fr } \\
\text { in corresp } \\
\text { in the fr }\end{array}$ & $\begin{array}{l}\text { ONV-II = s } \\
\text { were paired } \\
\text { ency occurr } \\
\text { ding harves } \\
\text { ency occurr }\end{array}$ & $\begin{array}{l}\text { of } 154 \\
\text { ased on } \\
\text { nce between } \\
\text { /ear. } \\
\text { nce between }\end{array}$ \\
\hline
\end{tabular}

$\mu \mathrm{g} / \mathrm{kg}$ and maximum value of $4,070 \mu \mathrm{g} / \mathrm{kg}$. The difference in DON contamination between ORG and CONV-I was statistically significant in the evaluation of data from all harvest years together $(P=0.004)$; however, the difference was only significant in $2016(P=0.038)$. In CONV-II, the proportion of DON-positive samples was 14\% (6, 28 and $6 \%$, respectively), with an average value of $23 \mu \mathrm{g} / \mathrm{kg}$ and a maximum measured value of $960 \mu \mathrm{g} / \mathrm{kg}$. The difference in DON contamination between ORG and CONV-II was not statistically significant. The DON content proved to be influenced by the harvest year in all three sample sets; DON content was higher in 2016 compared with 2015 and 2017.

The proportion of ZEN-positive samples was $4 \%$ in the ORG set, in individual years 0,9 and $2 \%$. The average value was $<2 \mu \mathrm{g} / \mathrm{kg}$, and the maximum detected value was $23 \mu \mathrm{g} /$

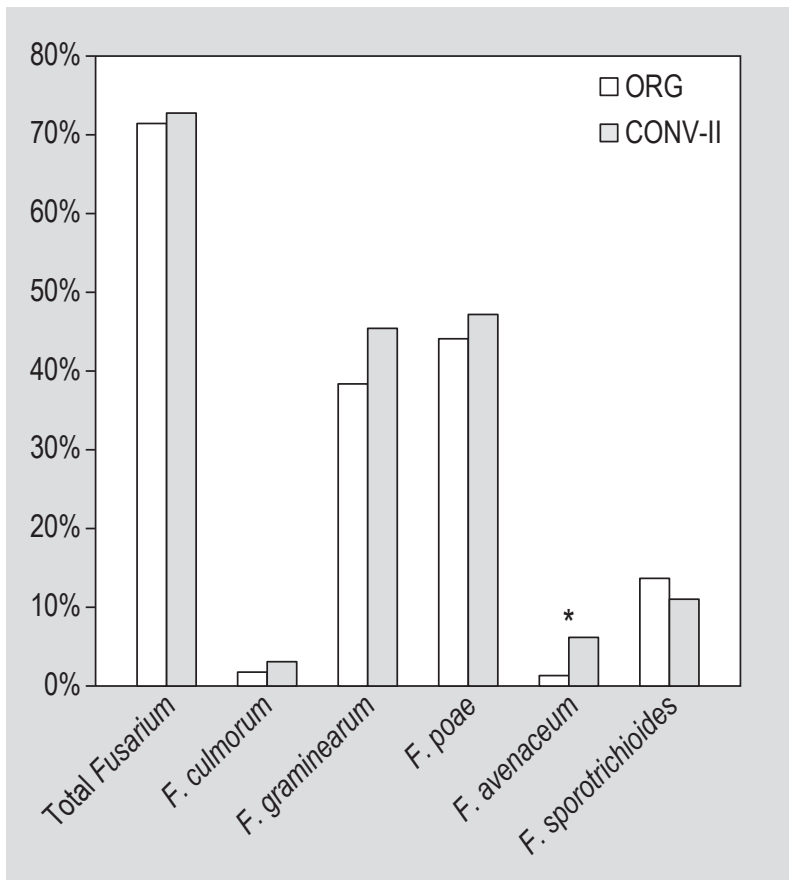

Figure 3. The occurrence of Fusarium species in organic and conventional wheat. The mean values for harvest years 20152017 are shown. ORG = set of 154 organic wheat samples; CONV-II = set of 154 wheat samples compatible to ORG, samples were paired based on location and preceding crop.

$\mathrm{kg}$ (Table 3). In the CONV-I sample set, the proportion of ZEN-positive samples was 9\% (3, 19 and 5\% in individual years), the mean value was $3 \mu \mathrm{g} / \mathrm{kg}$, and the maximum $118 \mu \mathrm{g} / \mathrm{kg}$. The difference between the ORG and CONV-I sample sets was at the edge of significance $(P=0.051)$. In CONV-II, the proportion of ZEN-positive samples was $3 \%$ (in individual years 0,6 and $4 \%$ ), and the average value was $<2 \mu \mathrm{g} / \mathrm{kg}$, the maximum detected value was $18 \mu \mathrm{g} / \mathrm{kg}$. ZEN contaminations in the ORG and CONV-II sample sets were comparable $(P=0.80)$. The influence of harvest year on ZEN was apparent neither in ORG nor in the CONV-II sample set. However, ZEN content proved to be higher in 2016 compared with 2015 and 2017 in CONV-I.

\section{Discussion}

\section{Methodology for comparison of mycotoxins and fungal occurrence in organic and conventional farming}

Several challenges are encountered when comparing fungal infection and mycotoxin contamination of cereals from organic and conventional farming. The approach to the sampling strategy seems to be crucial. Lester and Saftner (2011) concluded for the comparison of nutritional quality of organic and conventional agricultural produce, that accurate and meaningful conclusions are difficult to ascertain, unless pairing common production variables is applied. They proposed a large list of preharvest, harvest and postharvest 
Table 2. Comparison of deoxynivalenol content in organic and conventional wheat harvested in the Czech Republic, 2015-2017. ${ }^{1}$

\begin{tabular}{|c|c|c|c|c|c|c|c|c|}
\hline Group & Harvest year & $\begin{array}{l}\text { Number of } \\
\text { samples }\end{array}$ & $\begin{array}{l}\text { Percentage } \\
\geq \mathrm{LOQ}\end{array}$ & $\begin{array}{l}\text { Mean }^{2} \\
(\mu g / k g)\end{array}$ & $\begin{array}{l}\text { Median } \\
(\mu \mathrm{g} / \mathrm{kg})\end{array}$ & $\begin{array}{l}90 \% \text { percentile } \\
(\mu \mathrm{g} / \mathrm{kg})\end{array}$ & $\begin{array}{l}\text { Max } \\
(\mu g / \mathrm{kg})\end{array}$ & $P$-value ${ }^{3}$ \\
\hline \multirow[t]{3}{*}{ ORG } & 2015 & 48 & $2 \%$ & $<20^{b}$ & $<20$ & $<20$ & 141 & \\
\hline & 2016 & 53 & $26 \%$ & $25^{a}$ & $<20$ & 55 & 306 & \\
\hline & 2017 & 53 & $6 \%$ & $<20^{b}$ & $<20$ & $<20$ & 314 & \\
\hline 2015-2017 & & 154 & $12 \%$ & $<20$ & $<20$ & 26 & 314 & \\
\hline \multirow[t]{3}{*}{ CONV-I } & 2015 & 110 & $10 \%$ & $<20^{b}$ & $<20$ & 18 & 201 & 0.16 \\
\hline & 2016 & 110 & $37 \%$ & $148^{a}$ & $<20$ & 251 & 4,070 & 0.038 \\
\hline & 2017 & 110 & $15 \%$ & $75^{b}$ & $<20$ & 57 & 2,747 & 0.070 \\
\hline $2015-2017$ & & 330 & $21 \%$ & 80 & $<20$ & 78 & 4,070 & 0.004 \\
\hline \multirow[t]{3}{*}{ CONV-II } & 2015 & 48 & $6 \%$ & $<20^{b}$ & $<20$ & $<20$ & 98 & 0.73 \\
\hline & 2016 & 53 & $28 \%$ & $44^{\mathrm{a}}$ & $<20$ & 85 & 960 & 0.55 \\
\hline & 2017 & 53 & $6 \%$ & $<20^{b}$ & $<20$ & $<20$ & 69 & 0.77 \\
\hline 2015-2017 & & 154 & $14 \%$ & 23 & $<20$ & 26 & 960 & 0.64 \\
\hline
\end{tabular}

${ }^{1} \mathrm{ORG}=$ set of 154 organic wheat samples; CONV-I = set of 330 samples representing Czech conventional wheat harvest, 110 each harvest year; CONV-II = set of 154 wheat samples compatible to ORG, samples were paired based on location and preceding crop.

2 Different letters designate significant $(P<0.05)$ differences between years within groups.

${ }^{3} P$-value is related to differences in deoxynivalenol content between organic and conventional wheat in corresponding harvest year/all years.

Table 3. Comparison of zearalenone content in organic and conventional wheat harvested in the Czech Republic, 2015-2017. ${ }^{1}$

\begin{tabular}{|c|c|c|c|c|c|c|c|c|}
\hline Group & Harvest year & $\begin{array}{l}\text { Number of } \\
\text { samples }\end{array}$ & $\begin{array}{l}\text { Percentage } \\
\geq \text { LOD }\end{array}$ & $\begin{array}{l}\text { Mean }^{2} \\
(\mu \mathrm{g} / \mathrm{kg})\end{array}$ & $\begin{array}{l}\text { Median } \\
(\mu \mathrm{g} / \mathrm{kg})\end{array}$ & $\begin{array}{l}90 \% \text { percentile } \\
(\mu \mathrm{g} / \mathrm{kg})\end{array}$ & $\begin{array}{l}\text { Max } \\
(\mu \mathrm{g} / \mathrm{kg})\end{array}$ & $P$-value ${ }^{3}$ \\
\hline \multirow[t]{3}{*}{ ORG } & 2015 & 48 & $0 \%$ & $<2$ & $<2$ & $<2$ & $<2$ & \\
\hline & 2016 & 53 & $9 \%$ & $<2$ & $<2$ & $<2$ & 11 & \\
\hline & 2017 & 53 & $2 \%$ & $<2$ & $<2$ & $<2$ & 23 & \\
\hline 2015-2017 & & 154 & $4 \%$ & $<2$ & $<2$ & $<2$ & 23 & \\
\hline \multirow[t]{3}{*}{ CONV-I } & 2015 & 110 & $3 \%$ & $<2^{b}$ & $<2$ & $<2$ & 13 & 0.33 \\
\hline & 2016 & 110 & $19 \%$ & $6^{a}$ & $<2$ & 8 & 118 & 0.068 \\
\hline & 2017 & 110 & $5 \%$ & $<2^{b}$ & $<2$ & $<2$ & 42 & 0.54 \\
\hline $2015-2017$ & & 330 & $9 \%$ & 3 & $<2$ & $<2$ & 118 & 0.051 \\
\hline \multirow[t]{3}{*}{ CONV-II } & 2015 & 48 & $0 \%$ & $<2$ & $<2$ & $<2$ & $<2$ & - \\
\hline & 2016 & 53 & $6 \%$ & $<2$ & $<2$ & $<2$ & 18 & 0.83 \\
\hline & 2017 & 53 & $4 \%$ & $<2$ & $<2$ & $<2$ & 7 & 0.88 \\
\hline $2015-2017$ & & 154 & $3 \%$ & $<2$ & $<2$ & $<2$ & 18 & 0.80 \\
\hline
\end{tabular}

${ }^{1}$ ORG = set of 154 organic wheat samples; CONV-I = set of 330 samples representing Czech conventional wheat harvest, 110 each harvest year; CONV-II = set of 154 wheat samples compatible to ORG, samples were paired based on location and preceding crop.

2 Different letters designate significant $(P<0.05)$ differences between years within groups.

${ }^{3} P$-value is related to differences in zearalenone content between organic and conventional wheat in corresponding harvest year/all years.

factors to be paired in both organically and conventionally grown production systems that allow for a comparable produce quality study. According to Bernhoft et al. (2010), for the study of the significance of agricultural practice on mycotoxin levels in cereals, samples should be comparable at least concerning growth location, time of harvest and cereal species. However, most of the studies on comparison of mycotoxin contamination of organic and conventional cereals are based on unevenly numerous, randomly selected sets of organic and conventional samples. In our study, mycotoxin contamination of wheat was compared using two approaches, firstly based on randomly selected, unevenly numerous sets of organic and conventional samples, and secondly for matched sample sets paired according to the 
region of harvest and preceding crop. Presence of Fusarium species was analysed for the second approach only.

\section{Presence of Fusarium species}

Conventional PCR assays were used to detect fungi in wheat grains. The assays have many advantages over standard methods for the analysis of Fusarium contamination in plant material. They reduce detection time dramatically, are specific and sensitive, and do not require high expertise or expensive equipment (Jurado et al., 2006; Nicholson et al., 1998). On the other hand, qPCR assays, represent a significant advancement over conventional PCR technologies for diagnostic detection assays, offer better performances in terms of sensitivity, specificity and rapidity, are not prone to contamination, and also permit quantification of the target DNA (Casey and Dobson, 2004; Nicolaisen et al., 2009).

F. poae was the most common species in the mean of 3 harvest years (2015-2017), closely followed by F. graminearum. Their occurrence frequency did not differ between organic and conventional wheat but was greatly influenced by the harvest year. The only significant difference between organic and conventional wheat was observed in the presence of F. avenaceum. This species was one of the less frequent in both farming systems. F. avenaceum is reported to be favoured by direct drilling with cereals in crop rotation (Parikka et al., 2005), by fungicide use (Henriksen and Elen, 2005) and by glyphosate application (Fernandez et al., 2007). All these factors are attributed to conventional farming practices and could contribute to the more frequent occurrence of $F$. avenaceum in conventional wheat in our study. Bernhoft et al. (2010) found a significant difference between organic and conventional cereals in the occurrence of less frequent Fusarium species only, but the occurrence of the most frequent species was comparable, which is in agreement with our results. Karlsson et al. (2017) could not detect any difference in Fusarium communities in wheat from organic and conventional farming systems, similarly as Lazzaro et al. (2015). Vogelsgang et al. (2019) observed significantly higher F. graminearum incidence in the samples from conventional farms compared with those from organic farms and its occurrence was associated mainly with the previous crop maize. The incidence of F. poae was comparable. Their study was based on randomly selected samples. We compared Fusarium presence on samples paired according to the preceding crop. Maize as a preceding crop occurred only rarely (2 samples out of 154 ) in the set of organic samples and consequently in the set of paired conventional samples. Therefore, possible differences in Fusarium presence induced by the preceding crop were largely eliminated.
The general prevalence of $F$. poae and $F$. graminearum on wheat as shown in our study has been reported also in other recent studies (Chrpová et al., 2015; Lazzaro et al., 2015; Vogelsgang et al., 2019). F. poae is regarded to be more prevalent in warm and dry conditions (Xu et al., 2008), F. graminearum is commonly considered to be predominant in warm and humid regions (Nielsen et al., 2011). In our study, the occurrence of F. graminearum was promoted by a wet weather character in May-July period (harvest year 2016), whereas F. poae was the most abundant in the vegetation period with warm and dry May and June (harvest year 2017).

\section{Deoxynivalenol and zearalenone in organic and conventional wheat}

Depending on the approach to forming the sample set of conventional wheat, it was either that organic wheat contamination was lower than that of conventional wheat (for sets of randomly selected samples) or there was no difference (for compatible sets of organic and conventional samples paired with respect to the preceding crop and location of growing). The ambiguous results were concluded by Brodal et al. (2016), who reviewed dozens of studies reporting comparison of mycotoxin occurrence in organic and conventional cereals, the most often. From 30 papers focused on the DON content in wheat, 14 papers reported lower DON content in organic wheat, 14 papers did not find significant difference between organic and conventional wheat and 2 studies reported higher DON content in organic wheat. A more recent study from Switzerland, comprising 657 conventional and 29 organic wheat samples, revealed lower mycotoxin (DON, ZEN, nivalenol) content in organic wheat (Vogelsgang et al., 2019). Stanciu et al. (2017) compared the enniatin and beauvericin contaminations of 106 conventional and 27 organic wheat samples collected in Romania and discovered no difference in beauvericin content, whilst higher maximum values for enniatins were observed in conventional wheat, as well as higher incidences and mean levels in organic wheat. All above mentioned studies differed in the number of samples and in a sampling in general, most of them comparing unevenly numerous, randomly selected sample sets.

The only farm survey on mycotoxin contamination of organic and conventional cereals based on complementary paired sample sets was carried out by Bernhoft et al. (2010), who found a significantly lower DON content in organic wheat. This is in contrast to our results, as we found no difference between contamination of organic and conventional wheat based on paired sample sets. One of the reasons for the differing results could be the different criteria used for pairing samples, as the above mentioned study matched samples according to date of harvest, whereas we used preceding crop instead. Preceding crop plays very important role among the factors influencing 
FHB of cereals because Fusarium spp. inoculum comes from debris of host plants. As the primary sources of the infection are regarded to be maize and wheat residues (Krebs et al., 2000). Maize is generally considered to be a preceding crop significantly increasing the risk of contamination of subsequent wheat by Fusarium mycotoxins, not only as a direct preceding crop but also a higher proportion of maize in crop rotation in general (Edwards and Jennings, 2018; Vogelsgang et al., 2019). As well as, the wide spread of F. graminearum all over the Europe in the last 20 years is sometimes attributed to the vast expansion of maize production in Europe (Tillman et al., 2017). In our study, five out of seven samples with DON content above the limit of $1,250 \mu \mathrm{g} / \mathrm{kg}$ had maize as preceding crop, the same as the only sample having ZEN content above the limit of $100 \mu \mathrm{g} / \mathrm{kg}$. Besides of maize, as the promoting factor of Fusarium infestation and DON contamination was proved to be continuous cropping of cereal species and, in general, lack of crop rotation (Bernhoft et al., 2012). Crop rotation is one of the most often mentioned reasons for the differences in mycotoxin and Fusarium levels between organic and conventional cereals, in favour of organic agricultural practice, together with the use of mineral fertilisers and pesticides (Aldred and Magan, 2004; Bernhoft et al., 2012; Henriksen and Elen, 2005). An appropriate crop rotation is one of the basic principles of organic agriculture. In our study, the most often preceding crop of organic wheat was forage (58\%), followed by cereals (22\%) and oilseed crops (7\%). Maize occurred only rarely (1\%). On the other hand, among conventional preceding crops, forage accounted for $16 \%$, cereals for $22 \%$, oilseed crops for $43 \%$ and maize for $15 \%$. Not only the species of preceding crop itself but also the soil cultivation method can influence both the Fusarium species presence and the level of mycotoxin contamination, depending on preceding crop debris burial or removal. Reduced tillage has often been connected with the increased FHB intensity (Bernhoft et al., 2012; Váňová et al., 2008; Vogelsgang et al., 2019). As the greatest risk of mycotoxin development in grain was identified to be minimum tillage in combination with preceding crop maize (Edwards and Jennings, 2018; Vogelsgang et al., 2019). In our study, the information about soil cultivation method for individual samples included in the study was not available. In general, in the Czech conventional agricultural practice various methods of reduced soil cultivation are often applied and the percentage of such wheat fields is estimated to be around 50\%. On the other hand, in the local organic wheat growing practice soil tillage is far more predominant.

Wheat variety plays an important role among the FHB influencing agronomic factors. The cultivation of resistant varieties is regarded to be the most sustainable and cost-effective way to control yield losses and mycotoxin contamination (McMullen et al., 2012). In the organic agriculture, the role of varietal resistance is even more emphasised. The need of breeding specifically for organic farming systems has been accented, with a good disease resistance as one of the basic demands (Wolfe et al., 2008). In our study, the varietal composition of both organic and conventional wheat sample sets was widely diverse. Among the organic wheat samples, varieties Bohemia and Scaro occurred most frequently. Bohemia is a variety of Czech origin, classified as FHB moderately susceptible (Chrpová et al., 2010), which has been widely grown in both conventional and organic agricultural practice in CR. The variety Scaro was bred in Switzerland specifically for the purpose of organic agriculture and according to the breeder, the FHB resistance is classified as excellent. The most common varieties among conventional wheat samples were Tobak, Genius and Bohemia. Tobak is in the Czech conditions classified as very susceptible, and Genius as susceptible to FHB (Horáková and Dvořáčková, 2018). Comparing the varietal composition of organic and conventional sample sets it can be assumed that in organic farming, wheat varieties with better FHB resistance were grown.

Harvest year influenced the occurrence of Fusarium species and mycotoxin contamination in wheat grown in organic and conventional farming system in a similar way. Significantly higher mycotoxin content was observed in harvest year 2016, which was characterised by a wet weather conditions in May-July period. This year, F. graminearum was the most abundant species.

\section{Wheat samples exceeding legislation limits}

For organic wheat, the legal limits were not exceeded either for DON or ZEN and similarly for the paired set of conventional samples in any of the harvest years. In the randomly selected set of conventional wheat, the percentages of wheat samples exceeding the EU legal limits were in the mean of all harvest years $2.1 \%$ for DON and $0.3 \%$ for ZEN. According to the survey published by EFSA (2013), on average $0.8 \%$ of unprocessed cereal samples other than maize exceeded the legal limit for DON. Large year-to-year variability is common for the proportion of these above limit samples and was observed also in our study. The proportion of samples exceeding the legislation limit for DON varied between 0 and 4\%, for ZEN between 0 and $1 \%$. Vogelgsang et al. (2017) found 0-27\% of above limit wheat samples for DON and 0-12\% for ZEN, Edwards and Jennings (2018) 0-13\% for DON and 0-29\% for ZEN.

\section{Conclusions}

DON and ZEN contamination of organic wheat was found to be either lower or comparable with conventional wheat, depending on the approach to forming sets of conventional samples. Based on random sampling, mycotoxin contamination of organic wheat was lower than that of conventional wheat. Based on comparison of the matched set of conventional samples paired with the 
organic ones according to the preceding crop and the region of harvest, there was no difference. Higher contamination of conventional samples was related mostly to maize as preceding crop. The results emphasise the fact that for the studies of the significance of organic/conventional agricultural practice on mycotoxin levels in cereals, it is important to pay attention to matching common environmental inputs, as some of them can influence mycotoxin content more than the farming system itself. The study confirmed that organic farming system is able to keep mycotoxin contamination at a low level. The reason could be that the basic measures generally recommended for a Fusarium mycotoxin risk reduction, such as proper crop rotation, soil cultivation, and using more resistant varieties, are among the intrinsic principles of organic farming.

\section{Supplementary material}

Supplementary material can be found online at https://doi. org/10.3920/WMJ2020.2589.

Table S1. Wheat sample distribution by year and region, Czech wheat harvests 2015-2017.

Table S2. Frequency of wheat varieties in individual sample sets.

\section{Conflict of interest}

The authors declare no conflict of interest.

\section{Acknowledgements}

The research was funded by the Czech Ministry of Agriculture, projects No. QJ1510204 and MZE-RO1118.

\section{References}

Aldred, D. and Magan, N., 2004. Prevention strategies for trichothecenes. Toxicology Letters 153: 165-171. https://doi. org/10.1016/j.toxlet.2004.04.031

Becher, R., Miedaner, T. and Wirsel, S.G.R., 2013. Biology, diversity, and management of FHB-causing Fusarium species in small-grain cereals. In: Kempken, F. (eds.) Agricultural applications. The mycota Vol. 11. Springer, Berlin, Germany, pp. 199-241. https:// doi.org/10.1007/978-3-642-36821-9_8

Bernhoft, A., Clasen, P.-E., Kristoffersen, A.B. and Torp, M., 2010. Less Fusarium infestation and mycotoxin contamination in organic than in conventional cereals, Food Additives and Contaminants Part A 27: 842-852. https://doi.org/10.1080/19440041003645761

Bernhoft, A., Torp, M., Clasen, P.-E., Løes, A.-K. and Kristoffersen, A.B., 2012. Influence of agronomic and climatic factors on Fusarium infestation and mycotoxin contamination of cereals in Norway. Food Additives and Contaminants Part A 29: 1129-1140. https:// doi.org/10.1080/19440049.2012.672476
Brodal, G., Hofgaard, I.S., Eriksen, G.S., Bernhoft, A. and Sundheim, L., 2016. Mycotoxins in organically versus conventionally produced cereal grains and some other crops in temperate regions. World Mycotoxin Journal 9: 755-770. https://doi.org/10.3920/ WMJ2016.2040

Casey, G. and Dobson, A.D.W., 2004. Potential of using real-time PCR based detection of spoilage yeast in fruit juice - a preliminary study. International Journal of Food Microbiology 91: 327-335.

Chrpová, J., Šíp, V., Štočková, L., Milec, Z. and Bobková, L., 2010. Resistance of winter wheat varieties registered in the Czech Republic to Fusarium head blight in relation to the presence of specific $R h t$ alleles. Czech Journal of Genetics and Plant Breeding 46: 122-134.

Chrpová, J., Šíp, V., Sumíková, T., Salava, J., Palicová, J., Štočková, L., Džuman, Z. and Hajšlová, J., 2015. Occurrence of Fusarium species and mycotoxins in wheat grain collected in the Czech Republic. World Mycotoxin Journal 9: 317-327. https://doi.org/10.3920/ WMJ2015.1917

Czech Hydrometeorological Institute, 2019. Historical data. Available at: http://portal.chmi.cz/?l=en

Davies, G., Sumption, P. and Crockatt, M., 2002. Developing improved strategies for pest and disease management in organic vegetable production systems in the UK. In: Brighton Crop Protection Conference - Pests and Diseases. Brighton, UK, pp. 547-552.

Desjardins, A.E., 2006. Fusarium mycotoxins: chemistry, genetics, and biology. APS Press, St. Paul. MN, USA.

Doohan, F.M., Brennan, J. and Cooke, B.M., 2003. Influence of climatic factors on Fusarium species pathogenic to cereals. European Journal of Plant Pathology 109: 755-768. https://doi. org/10.1023/A:1026090626994

Edwards, S.G. and Jennings, P., 2018. Impact of agronomic factors on fusarium mycotoxins in harvested wheat. Food Additives and Contaminants Part A 35: 2443-2454. https://doi.org/10.1080/194 40049.2018.1543954

Edwards, S.G., 2004. Influence of agricultural practices on Fusarium infection of cereals and subsequent contamination of grain by trichothecene mycotoxins. Toxicology Letters 153: 29-35. https:// doi.org/10.1016/j.toxlet.2004.04.022

Edwards, S.G., 2009. Fusarium mycotoxin content of UK organic and conventional wheat. Food Additives and Contaminants Part A 26: 496-506. https://doi.org/10.1080/02652030802530679

European Food Safety Authority (EFSA), 2013. Deoxynivalenol in food and feed: occurrence and exposure. EFSA Journal 11: 3379. https://doi.org/10.2903/j.efsa.2013.3379

European Commission (EC), 2006. Commission Regulation (EC) No 1881/2006 of 19 December 2006 setting maximum levels for certain contaminants in foodstuffs. Official Journal of the European Union L 364: 5-24. Available at: https://tinyurl.com/y4y52xee

European Commission (EC), 2007. Council Regulation (EC) No $834 / 2007$ of 28 June 2007 on organic production and labelling of organic products and repealing Regulation (EEC) No 2092/91. Official Journal of the European Union L 189: 1-23. Available at: https://eur-lex.europa.eu/eli/reg/2007/834/oj

Fernandez, M.R., Zentner, R.P., DePauw, R.M., Gehl, D. and Stevenson, F.C., 2007. Impacts of crop production factors on Fusarium head blight in barley in Eastern Saskatchewan. Crop Science 47: 15741584. https://doi.org/10.2135/cropsci2006.09.0596 
Giménez, I., Escobar, J., Ferruz, E., Lorán, S., Herrera, M., Juan, T., Herrera, A. and Ariño, A., 2012. The effect of weather and agronomic practice on deoxynivalenol mycotoxin in durum wheat. Journal of Life Sciences 6: 513-517.

Harcz, P., De Temmerman, L., De Voghel, S., Waegeneers, N., Wilmart, O., Vromman, V., Schmit, J.-F., Moons, E., Van Peteghem, C., De Saeger, S., Schneider, Y.-J., Larondelle, Y. and Pussemier, L., 2007. Contaminants in organically and conventionally produced winter wheat (Triticum aestivum) in Belgium. Food Additives and Contaminants 24: 713-720. https:// doi.org/10.1080/02652030601185071

Henriksen, B. and Elen, O., 2005. Natural Fusarium grain infection level in wheat, barley and oat after early application of fungicides and herbicides. Journal of Phytopathology 153: 214-220. https:// doi.org/10.1111/j.1439-0434.2005.00955.x

Hoogenboom, L.A.P., Bokhorst, J.G., Northolt, M.D., Van de Vijver, L.P.L., Broex, N.J.G., Mevius, D.J., Meijs, J.A.C. and Roest, J., 2008. Contaminants and microorganisms in Dutch organic food products; comparison with conventional products. Food Additives and Contaminants Part A 25: 1195-1207. https://doi. org $/ 10.1080 / 02652030802014930$

Horáková, V. and Dvořáčková, O., 2018. SDO - oves setý, pšenice jarní, pšenice ozimá, ječmen jarní, ječmen ozimý, tritikale ozimé PO - tritikale jarní, oves nahý, žito ozimé. ÚKZÚZ, Brno, Czech Republic. Available at: http://eagri.cz/public/web/file/585839/ Obilniny_2018.pdf (in Czech)

Hrabalová, A. (ed.), 2016. Yearbook 2015: organic farming in the Czech Republic. Available at: http://eagri.cz/public/web/file/513472/ Roc_enka_EZ_2015_www_komplet.pdf.

Jurado, M., Vázquez, C., Marín, S., Sanchis, V. and GonzálezJaén, M.T., 2006. PCR-based strategy to detect contamination with mycotoxigenic Fusarium species in maize. Systematic and Applied Microbiology 29: 681-689. https://doi.org/10.1016/j. syapm.2006.01.014

Karlsson, I., Friberg, H., Kolseth, A.-K., Steinberg, C. and Persson, P., 2017. Organic farming increases richness of fungal taxa in the wheat phyllosphere. Molecular Ecology 26: 3424-3436. https://doi. org/10.1111/mec.14132

Kirinčič, S., Škrjanc, B., Kos, N., Kozolc, B., Pirnat, N. and TavčarKalcher, G., 2015. Mycotoxins in cereals and cereal products in Slovenia - official control of foods in the years 2008-2012. Food Control 50: 157-165. https://doi.org/10.1016/j.foodcont.2014.08.034

Kokkonen, M., Ojala, L., Parikka, P. and Jestoi, M., 2010. Mycotoxin production of selected Fusarium species at different culture conditions. International Journal of Food Microbiology 143: 1725. https://doi.org/10.1016/j.ijfoodmicro.2010.07.015

Krebs, H., Dubois, D., Külling, C., Forrer, H.R., Streit, B. and Richner, W., 2000. Effects of preceding crop and tillage on the incidence of Fusarium spp. and mycotoxin deoxynivalenol content in winter wheat grain. Agrarforschung 7: 264-268.

Lazzaro I., Moretti A., Giorni, P., Brera, C. and Battilani, P., 2015. Organic vs conventional farming: differences in infection by mycotoxin-producing fungi on maize and wheat in Northern and Central Italy. Crop Protection 72: 22-30. https://doi.org/10.1016/j. cropro.2015.03.001
Lester, G.E. and Saftner, R.A., 2011. Organically versus conventionally grown produce: common production inputs, nutritional quality, and nitrogen delivery between the two systems. Journal of Agricultural and Food Chemistry 59: 10401-10406. https://doi.org/10.1021/ jf202385x

Lori, G.A., Sisterna, M.N., Sarandón, S.J., Rizzo, I. and Chidichimo, H., 2009. Fusarium head blight in wheat: impact of tillage and other agronomic practices under natural infection. Crop Protection 28: 495-502. https://doi.org/10.1016/j.cropro.2009.01.012d

Malmauret, L., Parent-Massin, D., Hardy, J.-L. and Verger, P., 2002. Contaminants in organic and conventional foodstuffs in France. Food Additives and Contaminants 19: 524-532. https://doi. org/10.1080/02652030210123878

Marx, H., Gedek, B. and Kollarczik, B., 1995. Vergleichende Untersuchungen zum mykotoxikologischen Status von ökologisch und konventionell angebautem Getreide. Zeitschrift für Lebensmittel-Untersuchung und Forschung 201: 83-86. https:// doi.org/10.1007/BF01193206

McMullen, M., Bergstrom, G., De Wolf, E., Dill-Macky, R., Hershman, D., Shaner, G. and Van Sanford, D., 2012. A unified effort to fight an enemy of wheat and barley: Fusarium head blight. Plant Disease 96: 1712-1728. https://doi.org/10.1094/PDIS-03-12-0291-FE

Meister, U., 2009. Fusarium toxins in cereals of integrated and organic cultivation from the Federal State of Brandenburg (Germany) harvested in the years 2000-2007. Mycotoxin Research 25: 133. https://doi.org/10.1007/s12550-009-0017-z

Mesterházy, A., 2003. Breeding wheat for Fusarium head blight resistance in Europe. In: Leonard, K.J. and Bushnell, W.R. (eds.) Fusarium head blight of wheat and barley. APS Press, St. Paul, MN, USA, 312 pp.

Nicholson, P., Simpson, D.R., Weston, G., Rezanoor, H.N., Lees, A.K., Parry, D.W. and Joyce, D., 1998. Detection and quantification of Fusarium culmorum and Fusarium graminearum in cereals using PCR assays. Physiological and Molecular Plant Pathology 53: 17-37. https://doi.org/10.1006/pmpp.1998.0170

Nicolaisen, M., Suproniené, S., Nielsen, L.K., Lazzaro, I., Spliid, N.H. and Justesen, A.F., 2009. Real-time PCR for quantification of eleven individual Fusarium species in cereals. Journal of Microbiological Methods 76: 234-240. https://doi.org/10.1016/j.mimet.2008.10.016

Nielsen, L.K., Jensen, J.D., Nielsen, G.C., Jensen, J.E., Spliid, N.H., Thomsen, I.K., Justesen, A.F., Collinge, D.B. and Jørgensen, L.N., 2011. Fusarium head blight of cereals in Denmark: species complex and related mycotoxins. Phytopathology 101: 960-969. https://doi. org/10.1094/PHYTO-07-10-0188

Parikka, P., Hietaniemi, V. and Rämö, S., 2005. The effect of tillage on Fusarium infection and mycotoxins on barley and oats. In: Proceedings of the BCPC International Congress Crop Science \& Technology. Vol. 1. 31 October-2 November, 2005. SECC, Glasgow, UK, pp. 423-428.

Parry, D.W. and Nicholson, P., 1996. Development of a PCR assay to detect Fusarium poae in wheat. Plant Pathology 45: 383-391. https://doi.org/10.1046/j.1365-3059.1996.d01-133.x 
Perkowski, J., Wiwart, M., Buśko, M., Laskowska, M., Berthiller, F., Kandler, W. and Krska, R., 2007. Fusarium toxins and total fungal biomass indicators in naturally contaminated wheat samples from north-eastern Poland in 2003. Food Additives and Contaminants 24: 1292-1298. https://doi.org/10.1080/02652030701416566

Petr, J. and Reisnerová, H., 2009. Mycotoxins occurrence in organic farming cereal crops. Scientia Agriculturae Bohemica 40: 189-195.

Schaafsma, A.W. and Hooker, D.C., 2007. Climatic models to predict occurrence of Fusarium toxins in wheat and maize. International Journal of Food Microbiology 119: 116-125. https:// doi.org/10.1016/j.ijfoodmicro.2007.08.006

Schilling, A.G., Möller, E.M. and Geiger, H.H., 1996. Polymerase chain reaction-based assays for species-specific detection of Fusarium culmorum, F. graminearum, and F. avenaceum. Phytopathology 86: 515-522.

Stanciu, O., Juan, C., Miere, D., Loghin, F. and Mañes, J., 2017. Presence of enniatins and beauvericin in Romanian wheat samples: from raw material to products for direct human consumption. Toxins 9: 189. https://doi.org/10.3390/toxins9060189

Tillmann, M., Von Tiedemann, A. and Winter, M., 2017. Crop rotation effects on incidence and diversity of Fusarium species colonizing stem bases and grains of winter wheat. Journal of Plant Diseases and Protection 124: 121-130. https://doi.org/10.1007/s41348-016-0064-6

Turner, A.S., Lees, A.K., Rezanoor, H.N. and Nicholson, P., 1998. Refinement of PCR-detection of Fusarium avenaceum and evidence from DNA marker studies for phenetic relatedness to Fusarium tricinctum. Plant Pathology 47: 278-288. https://doi.org/10.1046/ j.1365-3059.1998.00250.x
Váňová, M., Klem, K., Míša, P., Matušinsky, P., Hajšlová, J. and Lancová, K., 2008. The content of Fusarium mycotoxins, grain yield and quality of winter wheat cultivars under organic and conventional cropping systems. Plant, Soil and Environment 54: 395-402. https:// doi.org/10.17221/411-PSE

Vogelgsang, S., Beyer, M., Pasquali, M., Jenny, E., Musa, T., Bucheli, T.D., Wettstein, F.E. and Forrer, H.-R., 2019. An eight-year survey of wheat shows distinctive effects of cropping factors on different Fusarium species and associated mycotoxins. European Journal of Agronomy 105: 62-77. https://doi.org/10.1016/j.eja.2019.01.002

Vogelgsang, S., Musa, T., Bänziger, I., Kägi, A., Bucheli, T.D., Wettstein, F.E., Pasquali, M. and Forrer, H.-R., 2017. Fusarium mycotoxins in Swiss wheat - a survey of growers' samples between 2007 and 2014 shows strong year and minor geographic effects. Toxins 9: 246. https://doi.org/10.3390/toxins9080246

Wilson, A., Simpson, D., Chandler, E., Jennings, P. and Nicholson, P., 2004. Development of PCR assays for the detection and differentiation of Fusarium spotrichioides and Fusarium langsethiae. FEMS Microbiology Letters 233: 69-76. https://doi.org/10.1016/j. femsle.2004.01.040

Wolfe, M.S., Baresel, J.P., Deslaux, D., Goldringer, I., Hoad, S., Kovacs, G., Löschenberger, F., Miedaner, T., Østergård, H. and Lammerts van Bueren, E.T., 2008. Developments in breeding cereals for organic agriculture. Euphytica 163: 323-346. https://doi.org/10.1007/s10681008-9690-9

Xu, X.M., Nicholson, P., Thomsett, M.A., Simpson, D., Cooke, B.M., Doohan, F.M., Brennan, J., Monaghan, S., Moretti, A., Mule, G., Homok, L., Beki, E., Tatnell, J., Ritieni, A. and Edwards, S.G., 2008. Relationship between the fungal complex causing Fusarium head blight of wheat and environmental conditions. Phytopathology 98: 69-78. https://doi.org/10.1094/PHYTO-98-1-0069 
